\title{
PENGARUH KEPEMIMPINAN KEPALA SEKOLAH, BUDAYA ORGANISASI DAN LINGKUNGAN KERJA TERHADAP PRESTASI KERJA GURU SEKOLAH DASAR PADA UNIT PELAKSANA TEKNIS DINAS DAERAH (UPTD) PENDIDIKAN, PEMUDA DAN OLAHRAGA KECAMATAN JEUNIEB KABUPATEN BIREUEN
}

\author{
Abdul Majid ${ }^{1)}$ dan Chairul Bariah*) \\ ${ }^{1}$ UPTD Disdik Kecamatan Jeunieb Kabupaten Bireuen \\ ${ }^{2}$ Dosen FE Universitas Almuslim Peusangan Bireuen \\ *) email: psmm.uniki@gmail.com
}

DOI:

https://doi.org/10.55178/idm.v2i3.212

ABSTRAK

Article history

Received:

March 10, 2021

Revised:

March 15, 2021

Accepted:

March 18, 2021

Page:

$32-41$

Kata kunci:

Principal leadership, organizational culture,

work environment,

teacher work performance
The purpose of this study was to determine 1) the influence of the principal's leadership on teacher performance, 2) the influence of organizational culture on teacher performance, 3) the influence of the work environment on teacher performance, and 4) the influence of the principal's leadership, organizational culture and work environment on performance. Elementary school teacher at the Regional Office for the Technical Implementation Unit for Education, Youth and Sports, Jeunieb District, Bireuen Regency. Methods of data analysis with a path analysis approach. The results showed that: a). There is an influence of the principal's leadership on teacher performance by $12.74 \%$. b). There is an influence of organizational culture on teacher performance by $10.95 \%$, and c). There is an influence of the work environment on teacher work performance by $21.95 \%$. Based on the magnitude of the determination coefficient of 0.509, it is explained that the contribution of the aspects of the principal's leadership, organizational culture and work environment to teacher performance is $50.9 \%$.

\section{Pendahuluan (Introduction)}

Pendidikan yang utama adalah pendidikan yang dilaksanakan di sekolah. Sekolah sebagai salah satu organisasi sosial yang berwenang menyelenggarakan pendidikan formal dalam kehidupan masyarakat untuk menghasilkan pribadi manusia yang berkualitas, karena pada era globalisasi berbagai macam aspek kehidupan harus mampu menyesuaikan dengan perkembangan zaman agar dapat menghadapi berbagai tantangan dengan baik, tanpa terkecuali aspek pendidikan juga harus mampu menyesuaikan diri pada perkembangan yang ada saat ini. Suatu lembaga pendidikan dapat dikatakan berkualitas apabila di dalamnya terdapat tenaga pendidik yang profesional, memiliki rasa tanggung jawab yang tinggi terhadap bidangnya, serta memiliki nilai moral dan budi pekerti yang luhur untuk dapat diakui sebagai tenaga pendidik. Untuk itu peningkatan kualitas di dalam pendidikan mutlak harus dilakukan, karena dengan begitu kualitas sumber daya manusia yang ada akan ikut terpengaruh.

Organisasi sekolah terhimpun dari berbagai unsur baik perseorangan maupun kelompok yang bekerja sama untuk mencapai tujuan pendidikan. Tanpa mengesampingkan unsur-unsur lain dari organisasi sekolah, maka kepala sekolah dan guru merupakan personal intern yang mempunyai peran penting dalam menentukan keberhasilan suatu proses pendidikan. Keberhasilan sekolah dalam proses penyelenggaraan pendidikan pada hakikatnya terletak pada efisiensi dan efektifitas dari penampilan kepala sekolah dalam menjalankan roda kepemimpinannya. Peran kepala sekolah sebagai pimpinan di sekolah memegang peranan penting dalam upaya menggerakkan jajaran guru untuk memiliki prestasi kerja yang tinggi dengan kepemimpinan yang 
selaras dengan lingkungan kerja, dan koordinasi yang matang. Kepala sekolah diharapkan mampu mengikut sertakan guru untuk melakukan proses pembelajaran secara optimal.

Kepala sekolah yang baik adalah kepala sekolah yang mempunyai sifat dan perilaku kepemimpinan yang baik dan dapat memberikan kompensasi yang berimbang kepada guru sehingga menimbulkan motivasi untuk berprestasi di kalangan mereka. Kepala sekolah hendaknya memiliki visi kelembagaan kemampuan konsepsional yang jelas, serta memiliki ketrampilan dan seni dalam hubungan antara manusia, penguasaan aspek-aspek teknis dan subtantif, memiliki semangat untuk maju serta semangat mengabdi dan karakter yang diterima masyarakat lingkungannya (Mulyasa, 2007: 84).

Paradigma baru manajemen pendidikan memberikan kewenangan luas kepada kepala sekolah dalam melakukan perencanaan, pengorgranisasian, pelaksanaan, pengawasan dan pengendalian pendidikan di sekolah. Mulyasa (2007: 89) mengatakan bahwa, "Kepala sekolah profesional dalam paradigma baru manajemen pendidikan akan memberikan dampak positif dan perubahan yang cukup mendasar dalam pembaharuan sistem pendidikan di sekolah".

Disanping itu dalam menningkatkan prestasi guru, adanya dukungan budaya sekolah. Budaya organisasi merupakan faktor penting bagi kinerja organisasi. Gibson, Ivancevich, dan Donnelly (2006:77) mengatakan bahwa "Budaya organisasi diartikan sebagai perpaduan nilai-nilai, kepercayaan, asumsi, persepsi, norma, kekhasan dan pola perilaku dalam suatu organisasi".

Adanya perkembangan masyarakat dan tuntutan terhadap kinerja sekolah agar memiliki keluaran (output) yang baik, maka sekolah perlu mengembangkan budaya organisasi sekolah yang mendukung pencapaian tujuan sekolah. Dengan demikian sekolah harus lebih profesional dan memiliki produktivitas yang tinggi dalam pengelolaan kegiatan- kegiatannya.

Faktor lain yang juga perlu diperhatikan adalah lingkungan kerja yang baik dan kondusif yang akan membuat guru merasa senang dan betah berada di ruangan kerja.Guru mau melaksanakan tugas di ruangan kerjanya sehingga dapat menghasilkan prestasi dan produktivitas kerja yang lebih baik dalam mencapai tujuan organisasi secara efektif dan efisien. Lingkungan kerja yang baik dan kondusif ditandai oleh perilaku para guru yang betah berada di tempat kerjanya. Apabila para guru merasa senang dan betah berada di ruangan kerjanya serta mampu melaksanakan tugas dengan baik, maka lingkungan kerja tersebut baik dan kondusif.

Dari hasil obserfasi awal peneliti pada Sekolah Dasar pada Lingkungan Unit Pelaksana Teknis Dinas Daerah (UPTD) Pendidikan, Pemuda dan Olahraga Kecamatan Jeunieb Kabupaten Bireuen terdapat ada beberapa masalah yang tejadi antara lain, 1) kepemimpinan kepala sekolah cenderung membuat pengembangan diri guru rendah, dikarenakan kemunculan daya kreatif untuk berprestasi yang lebih baik kurang memperoleh penghargaan dari pimpinan sekolah sehingga dianggap tidak penting, 2). Budaya di sekolah masih berada pada kondisi yang belum ideal. Masih ditemukan sebagian guru sekolah yang kurang memahami norma yang berlaku, terlihat beberapa guru sekolah yang selain datang ke sekolah terlambat dari waktu yang ditentukan, pulang lebih awal, atau masih tetap berada di luar ruangan pada saat jam kerja, dan 3). Lingkungan kerja pada Sekolah Dasar setempat masih ditemukan kondisi ruang kerja kurang nyaman, termasuk keberadaan peralatan kerja, yang peneliti duga sementara akan berdampak pada kurang optimalnya prestasi kerja yang dicapai paraa guru Sekolah Dasar tersebut.

\section{Tinjauan Literatur (Literature Review)}

\section{a. Pengaruh Kepemimpinan Kepala Sekolah terhadap Prestasi Kerja Guru}

Salah satu tugas kepala sekolah adalah sebagai pemimpin pendidikan, yaitu memimpin staff (guru-guru, pegawai dan pesuruh), membina kerjasama yang harmonis antar anggota staf sehinggga dapat membangkitkan semangat kerja, motivasi kerja bagi staf yang dipimpin serta menciptakan suasana yang konduktif. Kepemimpinan yang bagus, kerjasama yang harmonis serta suasana yang konduktif menjamin staf menjadi senang untuk melaksanakan tugas dengan sebaik-baiknya. Disamping itu kepemimpinan kepala sekolah merupakan kunci proses pemberdayaan kegiatan pendidikan di sekolah. Unsur kepemimpinan kepala sekolah adalah pengaruh yang dimilikinya dan kemampuan menggunakan pengaruh tersebut serta akibat pengaruh itu bagi orang yang hendak dipengaruhi yaitu para guru, pegawai, dan warga sekolah lainnya. Pengaruh tersebut diwujudkan melalui fungsi kepemimpinan kepala sekolah yaitu charisma, idealized influence, inspirational motivation, intellectual stimulation, individual consideration. Pengelolaaan fungsi kepemimpinan kepala sekolah tersebut dapat memberikan pengaruh terhadap kinerja guru, dengan demikian keberhasilan tujuan pendidikan akan mudah tercapai. Rivai (2007:2) 
Dalam mempimpin guru dan pegawai setiap top maupun middle management memiliki fungsi kekepimpinan masing-masing. Kepemimpinan yang digunakan adalah fungsi kepemimpinan charisma, idealized influence, inspirational motivation, intellectual stimulation, dan individual consideration. Keberhasilan pendidikan di sekolah bukan saja ditentukan oleh kepemimpinan pemimpin, melainkan juga para bawahan (guru, dan pegawai) sebagai pelaksana akan memberikan peranan yang sangat penting dalam sekolah. Kepemimpinan seorang pemimpin pada umumnya ingin merefleksikan sifat-sifat dan tujuan dari kelompoknya. Keberhasilan organisasi atau perubahan juga sangat ditentukan oleh keberhasilan pemimpin dengan kepemimpinan dalam melaksanakan fungsi dan tugasnya. Pelaksanaan suatu kepemimpinan tidak terlepas dari perilaku atau cara-cara yang diterapkan oleh pemimpin dalam mempengaruhi bawahannya, sehingga bawahan akan menjalankan tugas atau pekerjaannya secara efektif dan produktif juga pemimpin menerapkan fungsi kepemimpinan tertentu, maka kinerja guru terhadap kepemimpinan kepala sekolah akan sangat baik. (Wahyudi, 2009)

Tolok ukur dari kinerja guru sendiri meliputi aktivitas yang berkaitan dengan perencanaan pengajaran, pelaksanaan proses pengajaran, pelaksanaan penilaian pengajaran, dan tindak lanjut penilaian. Di samping itu motivasi kerja guru sebagai perangsang keinginan dan daya gerak yang menyebabkan seorang guru bersemangat dalam mengajar. Guru yang bersemangat dalam mengajar terlihat dalam ketekunannya ketika melaksanakan tugas, ulet, minatnya yang tinggi dalam memecahkan masalah, penuh kreatif dan sebagainya. Hal ini berdampak pada prestasi kerja, teori diatas dapat dikemukakan bahwa terdapat pengaruh antara kepemimpinan kepala sekolah terhadap kinerja guru. (Abdul Azis Wahab, 2008)

\section{b). Pengaruh Budaya Organisasi terhadap Prestasi Kerja Guru}

Sekolah merupakan suatu organisasi, dan budaya yang ada di tingkat sekolah merupakan budaya organisasi. Resep utama budaya organisasi adalah interpretasi kolektif yang dilakukan oleh anggota-anggota organisasi berikut hasil aktivitasnya. Budaya organisasi merupakan norma-norma dan nilai-nilai yang mengarahkan perilaku anggota organisasi. Budaya selalu mengalami perubahan, hal ini sesuai dengan peranan sekolah sebagai agen perubahan yang selalu siap untuk mengikuti perubahan yang terjadi. Maka budaya organisasi sekolah diharapkan juga mampu mengikuti, menyeleksi, dan berinovasi terhadap perubahan yang terjadi. Tilaar (2004:41) mengemukakan bahwa kebudayaan dan pendidikan merupakan dua unsur yang tidak dapat dipisahkan karena saling mengikat. Budaya itu hidup dan berkembang karena proses pendidikan, dan pendidikan itu hanya ada dalam suatu konteks kebudayaan. Yang ada dalam arti kurikulum adalah sebagai rekayasa dari pembudayaan suatu masyarakat, sedangkan proses pendidikan itu pada hakekatnya merupakan suatu proses pembudayaan yang dinamik.

Budaya organisasi sekolah yang positif dapat mempengaruhi terselenggaranya pendidikan yang bermutu tinggi serta pembentukan sikap dan moral yang positif bagi segenap personel yang ada dalam lembaga pendidikan. Kondisi yang demikian ini sangat mendukung pencapaian prestasi belajar yang tinggi. Para pakar administrasi dan manajemen pendidikan sejak dekade 1980-an secara tegas meletakkan tanggung jawab kepala sekolah sebagai pencipta budaya sekolah yang kondusif dan ciri sekolah yang efektif (Lipham \& Hoeh, 1985). DeRoche menegaskan bahwa kepala sekolah memiliki tanggung jawab utama dalam rangka penataan budaya organisasi sekolah. Hal ini menunjukkan bahwa kepala sekolah memegang peranan yang sangat menentukan dalam menciptakan keberhasilan di sekolah (Hikmah Eva Trisnantari, 2009:22).

Creemers dan Renolds (2002) dalam Himah Eva Trisnantari (2009:.23) mengungkapkan hasil penelitiannya bahwa kepemimpinan mempunyai peranan dalam menciptakan realitas organisasi dan membentuk budaya organisasi. Produktivitas organisasi termasuk di dalamnya adalah kinerja guru akan bisa terwujud jika ditopang oleh budaya organisasi yang kuat dan iklim organisasi yang kondusif. Hal tersebut menunjukkan bahwa gaya kepemimpinan yang diterapkan oleh kepala sekolah akan mempengaruhi terbentuknya budaya dan iklim organisasi yang ada di sekolah.

Robbins (2003:721) mengemukakan bahwa terdapat beberapa karakteristik primer yang menentukan sifat budaya organisasi, yakni: 1. Innovasi dan pengambilan resiko, 2. Perhatian terhadap detail, 3. Orientasi terhadap hasil, 4. Orientasi orang yang memperlihatkan tentang keputusan manajemen terhadap individuindividu, 5. Orientasi Tim terhadap kegiatan kerja, 6. Keagresifan yang menunjukan sejauh mana personil organisasi itu agresif dan kompetitif, dan 7. Kemantapan yang menunjukan sejauh mana kegiatan organisasi menekankan dipertahankannya status quo bukannya pertumbuhan.

\section{c. Pengaruh Lingkungan Kerja terhadap Prestasi Kerja Guru}

Keberhasilan suatu organisasi dalam mencapai tujuan juga tidak terlepas dari faktor lingkungan kerja. Meskipun faktor tersebut sangat penting tetapi masih banyak organisasi yang kurang memperhatikan hal 
tersebut. Lingkungan kerja adalah segala sesuatu yang ada disekitar para pekerja dan dapat mempengaruhi dirinya dalam menjalankan tugas-tugas yang dibebankan. Misalnya kebersihan, musik dan lain-lain (Nitisemito, 2001: 183). Dari sinilah dapat dikatakan bahwa lingkungan unit kerja dapat berpengaruh terhadap pekerjaan yang dilakukan, sehingga setiap organisasi atau unit kerja yang ada harus mengusahakan agar faktor-faktor yang termasuk dalam lingkungan kerja dapat diusahakan sedemikian rupa sehingga nantinya mempunyai pengaruh yang positif bagi organisasi itu sendiri.

Menurut Sedarmayanti (2001: 21) lingkungan kerja dibedakan menjadi lingkungan fisik dalam arti semua keadaan yang terdapat di sekitar tempat kerja akan mempengaruhi pegawai baik secara langsung, misalnya pusat kerja, kursi, meja, maupun secara tidak langsung misalnya rumah, kantor, sekolah, sistem, jalan raya, dan lain-lain. Selain lingkungan fisik ada juga lingkungan kerja yang dapat mempengaruhi kondisi manusia yang disebut dengan lingkungan perantara, misalnya temperatur, kelembaban, sirkulasi udara, pencahayaan, kebisingan, bau tak sedap, warna, dan lain-lain. Lingkungan dimana seseorang melakukan segala aktivitasnya akan mempengaruh lingkungan kerja.

Berdasarkan uraian di atas penulis dapat menggambarkan kerangka pemikiran sebagai berikut :

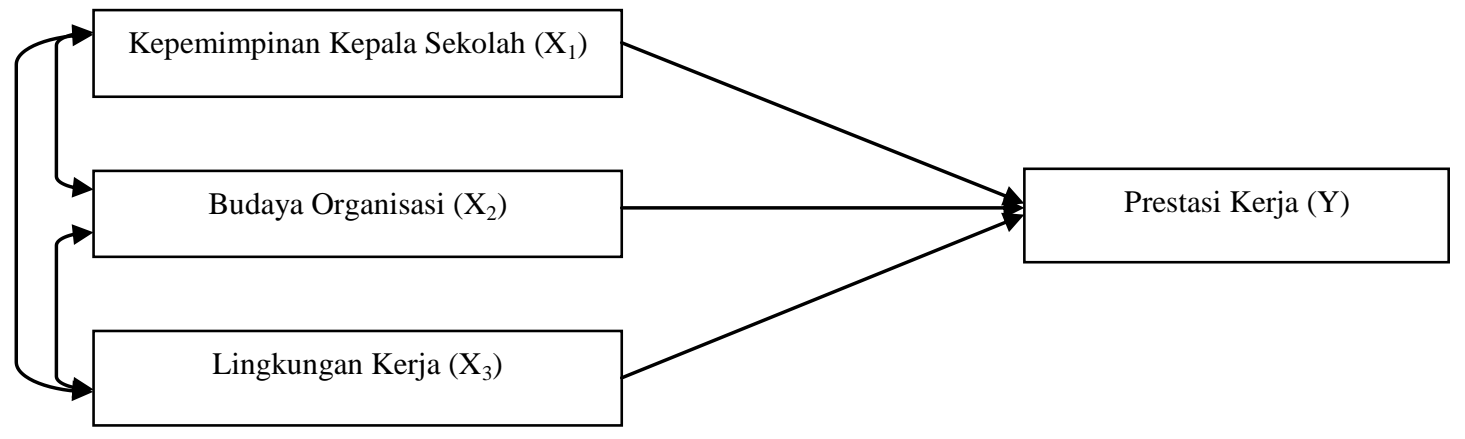

Gambar 1. Kerangka Pemikiran

\section{Metode Penelitian (Methodology)}

\section{a. Metode dan Variabel Penelitian}

Metode penetian yang akan digunakan dalam penelitian ini adalah metode asosiatif dengan pendekatan kuantitatif. Metode asosiatif merupakan metode yang bermaksud untuk menjelaskan hubungan kausal dan pengaruh antara variabel-variabel melalui pengujian hipotesis. Menurut Sugiyono (2012:11) menyatakan bahwa pengertian asosiatif adalah Penelitian yang bertujuan untuk mengetahui pengaruh ataupun hubungan antara dua variabel atau lebih

Adapun variabel, dimensi dan indikator pengukurnya di definisikan berikut ini.

Tabel 1. Operasional Variabel Penelitian

\begin{tabular}{|l|l|l|}
\hline \multicolumn{1}{|c|}{ Variabel } & \multicolumn{1}{|c|}{ Defenisi Konsep } & \multicolumn{1}{|c|}{ Indikator } \\
\hline Kepemimpinan & Kepemimpinan adalah proses mempengaruhi & 1. Kecerdasan (Intelligence) \\
$\left(\mathrm{X}_{1}\right)$ & atau memberi contoh kepada pengikut- & 2. Kedewasaan, Sosial dan hubungan Sosial \\
& pengikutnya lewat proses komunikasi dalam & yang luas \\
& upaya mencapai tujuan organisasi. Keseluruhan & 3. Motivasi diri dan dorongan berprestasi \\
& tindakan guna mempengaruhi serta & 4. Sikap-sikap hubungan manusiawi \\
& menggiatkan orang dalam usaha bersama untuk & 5. Memiliki Pengaruh yang kuat \\
& mencapai tujuan, atau dengan definisi yang & 6. Memiliki pola hubungan yang baik \\
& lebih lengkap dapat dikatakan bahwa & 7. Memiliki Sifat-Sifat Tertentu \\
& kepemimpinan adalah proses pemberian jalan & 8. Memiliki kedudukan atau jabatan \\
& yang mudah dari pada pekerjaan orang lain & 9. Mampu berinteraksi \\
& yang terorganisir dalam organisasi formal guna & 10Mampu Memberdayakn bawahan \\
& mencapai tujuan yang telah ditetapkan. Rivai & \\
& (2007:2) & \\
\hline Budaya organisasi & Budaya organisasi sebagai sebuah sistem & 1. Integritas \\
& makna (persepsi) bersama yang dianut oleh & 2. Profesionalisme \\
& anggota-anggota organisasi, yang membedakan & 3. Keteladanan \\
& organisasi tersebut dengan oganisasi lainnya. & 4. Penghargaan pada Sumber Daya Manusia \\
& Robbins dan Timoty (2008:256) & \\
\hline
\end{tabular}




\begin{tabular}{|c|c|c|}
\hline $\begin{array}{l}\text { Lingkungan Kerja } \\
\left(\mathrm{X}_{3}\right)\end{array}$ & $\begin{array}{l}\text { Lingkungan kerja adalah keseluruhan alat } \\
\text { perkakas dan bahan yang dihadapi lingkungan } \\
\text { sekitarnya dimana seseorang bekerja, metode } \\
\text { kerjanya, serta pengaturan kerjanya baik } \\
\text { sebagai perseorangan maupun sebagai } \\
\text { kelompok. Kondisi lingkungan kerja dikatakan } \\
\text { baik atau sesuai apabila manusia dapat } \\
\text { melaksanakan kegiatan secara optimal, sehat, } \\
\text { aman dan nyaman. Sedarmayanti (2006:8) }\end{array}$ & $\begin{array}{l}\text { 1. Lingkungan Kerja Fisik } \\
\text { 2. Lingkungan Kerja Non Fisik }\end{array}$ \\
\hline $\begin{array}{l}\text { Prestasi Kerja } \\
(\mathrm{Y})\end{array}$ & $\begin{array}{l}\text { Prestasi adalah tingkat kecakapan seseorang } \\
\text { pada tugas-tugas yang mencakup pada } \\
\text { pekerjaan. } \\
\text { Sutrisno }(2010: 150)\end{array}$ & $\begin{array}{l}\text { 1. Hasil kerja. } \\
\text { 2. Pengetahuan pekerjaan. } \\
\text { 3. Inisiatif. } \\
\text { 4. Kecekatan mental. } \\
\text { 5. Sikap. } \\
\text { 6. Disiplin waktu dan absensi. }\end{array}$ \\
\hline
\end{tabular}

\section{b. Populasi dan Sampel Penelitian}

Populasi yang akan diteliti dalam penelitian ini adalah seluruh Guru pada Unit Pelaksana Teknis Dinas (UPTD) Pendidikan, Pemuda Dan Olahraga Kecamatan Jeunieb Kabupaten Bireuen. Total populasi yang digunakan dalam penelitian berjumlah 398 Orang guru dari 27 unit Sekolah Dasar (SD).

Teknik pengambilan sampel pada penelitian ini menggunakan teknik probability sampling, yaitu teknik pengambilan sampel yang memberikan peluang yang sama bagi setiap 398 unsur (guru) populasi untuk dipilih sebagai anggota sampel. Penentuan jumlah sampel dalam penelitian ini menggunakan rumus Slovin. Sugiyono (2011:87), yakni $\mathbf{n}=\mathbf{N} /\left(\mathbf{1}+\mathbf{N} .(\mathbf{e})^{2}\right.$ dengan asumsi taraf kesalahan (e) sebesar 5\%, maka jumlah sampel yang diambil minimal 115 guru.

\section{c. Alat Analisis}

Metode analisis data menggunakan pendekatan Analisis Jalur (Path Analysis). Analisis jalur digunakan untuk mengetahui besarnya pengaruh suatu variabel terhadap variabel lainnya baik pengaruh langsung maupun tidak langsung. Langkah dalam melakukan analisis data dengan menggunakan analisis jalur sesuai dengan modifikasi dari Harun dalam Nirwana (2014:19-28). Besarnya pengaruh variabel bebas terhadap variabel terikat disebut koefisien jalur.

Analisis jalur ialah suatu teknik untuk menganalisis hubungan sebab-akibat yang terjadi pada regresi berganda jika variabel bebasnya mempengaruhi variabel tergantungnya tidak hanya secara langsung, tetapi juga secara tidak langsung" (Robert D. Rutherford, 1993, dalam Marwan Hamid, dkk; 2019:10).

Analisis jalur merupakan bagian dari model regresi yang dapat digunakan untuk menganalisis hubungan sebab akibat antar satu variabel dengan variabel lainnya. Dalam analisis jalur pengaruh independen dan dependen dapat berupa pengaruh langsung dan pengaruh tidak langsung (direct indirect effect), atau dengan kata lain analisis jalur memperhitungkan adanya pengaruh langsung dan tidak langsung.

Untuk menggambarkan hubungan-hubungan kausalitas antarvariabel yang akan diteliti pada penelitian ini digunakan diagram jalur (pathdiagram). Diagram jalur (path diagram) adalah alat untuk melukiskan secara grafis, struktur hubungan kausalitas antara variabel eksogen (independen),dan variabel endogen (dependen).

Analisis jalur ini mengikuti pola struktural atau disebut model struktural. Model struktural secara umum dapat digambarkan dengan persamaan sebagai berikut : $\mathrm{Y}=f\left(\mathrm{X}_{1}, \mathrm{X}_{2}, \mathrm{X}_{3}\right)$. Diagram jalur dan persamaan struktural penelitian ini adalah seperti terlihat pada Gambar 1 berikut :

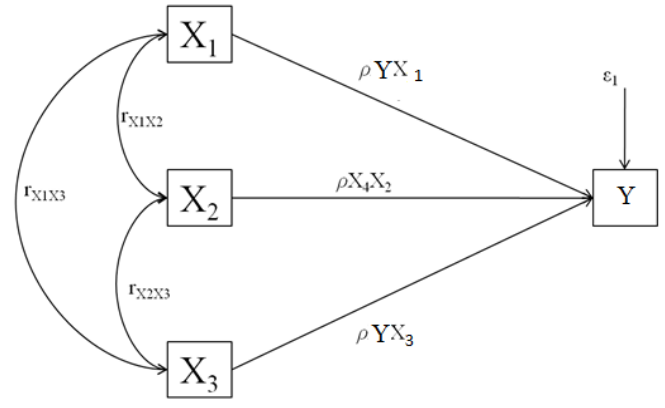

Keterangan :

$\mathrm{Y}=$ Prestasi Kerja Guru

$\mathrm{X}_{1}=$ Kepemimpinan Kepala Sekolah

$\mathrm{X}_{2}=$ Budaya Organisasi

$\mathrm{X}_{3}=$ Lingkungan Kerja

$\varepsilon=$ Epsilon, yaitu menunjukkan variabel atau faktor residual yang menjelaskan pengaruh variabel lain yang tidak diteliti.

$r_{x i, x j}=$ hubungan kausal antar variabel eksogen di ukur dengan koefisien korelasi

$\rho_{\mathrm{yxi}}=$ Nilai Koefisien Jalur (Path)

Gambar 1 Diagram Jalur Penelitian 


\section{Hasil dan Pembahasan (Results and Discussion)}

\section{a. Karakteristik Responden}

Jumlah responden pada Unit Pelaksana Teknis Dinas Daerah (UPTD) Pendidikan, Pemuda Dan Olahraga Kecamatan Jeunieb Kabupaten Bireuen yang berumur 18-25 tahun sebanyak 19 orang atau 16,5\%, responden yang berumur 26-35 tahun sebanyak 21 orang atau 18,3\%, sedangkan responden yang berumur 36-45 tahun sebanyak 45 orang atau 39,1\%, sedangkan responden yang berumur $>45$ tahun sebanyak 30 orang atau $26,1 \%$.

Jumlah responden berdasarkan pendidikan terakhir pada tingkat SMA berjumlah tidak ada, untuk tingkat pendidikkan Diploma berjumlah 20 orang atau 17,4\%, sedangkan pada tingkat pendidikan Sarjana (S1) berjumlah 87 orang atau 75,7\%, pada jenjang pendidikan Pascasarjana (S2) berjumlah 8 orang atau 7,0\%.

\section{b. Hasil analisis Deskriptif}

Analisis deskriptif akan menunjukkan gambaran mengenai suatu data yang akan diteliti atau untuk menguraikan kecenderungan jawaban responden dari tiap-tiap variabel. Berdasarkan hasil kuesioner yang telah teruji validitas dan reliabilitasnya, dari 115 guru guru SD, diperoleh deskripsi setiap variabel yang diteliti, sebagai berikut.

Tabel 2. Deskripsi Guru tentang Variabel Penelitian

\begin{tabular}{|c|c|c|c|c|c|c|}
\hline \multirow{2}{*}{ Variabel } & \multicolumn{5}{|c|}{ Persentase Jawaban } & \multirow{2}{*}{$\begin{array}{c}\text { Skor } \\
\text { Pencapaian }\end{array}$} \\
\hline & SS & $\mathbf{S}$ & KS & TS & STS & \\
\hline 1. Kepemimpinan Kepala Sekolah & 24.43 & 63.39 & 12.09 & 0.09 & 0.00 & 82,08 \\
\hline 2. Budaya organisasi sekolah & 26.74 & 60.11 & 11.41 & 1.63 & 0.11 & 82,34 \\
\hline 3. Lingkungan kerja & 22.83 & 68.04 & 8.48 & 0.65 & 0.00 & 82,60 \\
\hline 4. Prestasi guru & 23.48 & 58.37 & 5.54 & 0.11 & 0.00 & 84,04 \\
\hline
\end{tabular}

Sumber : Hasil Peneltian, 2020 (data diolah, dengan SPSS)

Catatan $: S S=$ Sangat setuju, $S=$ Setuju, KS = Kurang setuju, $T S=$ Tidak setuju STS = Sangat tidak setuju)

Berdasarkan tabel di atas dapat dijelaskan bahwa :

1) Faktor Kepemimpinan Kepala Sekolah, menurut persepsi guru termasuk baik dalam mendukung prestasi kerja guru. Skor penilaian guru atas Kepemimpinan Kepala Sekolah mencapai 82,08\%

2) Faktor Budaya organisasi di sekolah, sudah baik mencapai $82,34 \%$ dari kondisi yang ideal,

3) Faktor dukungan lingkungan kerja terhadap prestasi guru juga masuk kategori baik, mencapai $82,60 \%$,

4) Tingkat prestasi guru sudah mencapai kategori baik, yakni $84,04 \%$, walaupun masih bisa dioptimalkan lagi.

\section{c. Hasil Analisis Jalur}

Dalam penelitian ini model analisis dengan analisi jalur yang menentukan Kepemimpinan Kepala Sekolah, Budaya organisasi, dan Lingkungan kerja terhadap Prestasi kerja guru. Dengan model $\mathrm{Y}=\mathrm{f}(\mathrm{X} 1, \mathrm{X} 2, \mathrm{X} 3)=$ $\rho_{1} X_{1}+\rho_{2} X_{2}+\rho_{3} X_{3}+$ e. Adapun pembuktian hipotesis secara simultan dapat dilihat pada tabel berikut ini:

Tabel 3. Uji Model Sruktural (Uji Secara Simultan)

\begin{tabular}{|l|l|r|r|r|r|r|}
\hline \multicolumn{1}{|l|}{ Model } & Sum of Squares & df & Mean Square & \multicolumn{1}{c|}{ F } & \multicolumn{1}{c|}{ Sig. } \\
\hline Regression & 101.044 & 3 & 33.681 & 5.323 & $.002^{\mathrm{a}}$ \\
\hline Residual & 702.399 & 111 & 6.328 & & \\
\hline Total & 803.443 & 114 & & & \\
\hline
\end{tabular}

a. Predictors: (Constant), Lingkungan Kerja, Budaya Organisasi, Kepemimpinan Kepala Sekolah

b. Dependent Variable: Prestasi Kerja

Sumber: Data olahan, 2020 (diolah dengan SPSS)

Berdasarkan hasil uji $\mathrm{F}$ diperoleh nilai $\mathrm{F}_{\text {hitung }}$ sebesar 5,323. Sementara nilai signifikansinya 0,002. Hal ini menunjukkan model regresi antar variabel signifikansi linier. Maka model analisi jalur dalam bentuk $\mathrm{Y}=$ $f(X 1, X 2, X 3)=\rho_{1} X_{1}+\rho_{2} X_{2}+\rho_{3} X_{3}$ diterima.

\section{1). Pengujian Hipotesis Penelitian}

Dalam hal ini hipotesis yang diajukan selanjutnya diuji untuk menjawab masalah penelitian yang dirumuskan, yakni: 
Hasil pengolahan data dalam menaksir koefisiein jalur dan uji signifikansinya;

Tabel 4. Taksiran Koefisien Jalur Variabel Bebas (Eksogenus) dan Uji-t

\begin{tabular}{|l|c|c|c|}
\hline \multirow{2}{*}{ Model } & Unstandardized Coefficients & \multirow{2}{*}{ Sig. } \\
\cline { 2 - 3 } & Beta & & \\
\hline Kepemimpinan Kepala Sekolah & 0.261 & 2.605 & 0.000 \\
\hline Budaya Organisasi & 0.246 & 2.495 & 0.000 \\
\hline Lingkungan Kerja & 0.370 & 3.742 & 0.000 \\
\hline
\end{tabular}

a. Dependent Variable: Prestasi Kerja

Hipotesis-1:

Ho: $\rho_{\mathrm{zx} 1} \leq 0$ : Kepemimpinan Kepala Sekolah tidak berpengaruh terhadap Prestasi kerja guru

$\mathrm{H}_{1}: \rho_{\mathrm{zx} 1}>0$ : Kepemimpinan Kepala Sekolah berpengaruh terhadap Prestasi kerja guru

Kriteria pengujian adalah total Ho jika $t_{\text {hitung }}>t_{\text {tabel }}$ dimana $t_{\text {tabel }}$ untuk $\alpha=5 \%$ adalah 1,981. Hipotesis ini menyatakan ada pengaruh Kepemimpinan Kepala Sekolah $\left(\mathrm{X}_{1}\right)$ terhadap Prestasi kerja guru (Y). Dengan koefisien jalurnya $\rho_{\mathrm{yx} 1}=0,261$. Hasil perhitungan uji individu menunjukkan harga $\mathrm{t}_{\text {hitung }}$ sebesar 2,605. Dengan demikian $t_{\text {hitung }}>t_{\text {tabel }}(2,605>1,981)$. Sehingga Ho ditolak dan $H_{1}$ diterima artinya koefisien jalur Kepemimpinan Kepala Sekolah $\left(\mathrm{X}_{1}\right)$ terhadap Prestasi kerja guru $(\mathrm{Y})$ dapat dinyatakan signifikan pada taraf signifikan $\alpha=0,05$.

Hipotesis 2

Ho: $\rho_{\mathrm{yx} 2} \leq 0$ : Budaya organisasi tidak berpengaruh terhadap Prestasi kerja guru

$\mathrm{H}_{1}: \rho_{\mathrm{yx} 2}>0$ : Budaya organisasi berpengaruh terhadap Prestasi kerja guru

Hipotesis ini menyatakan ada pengaruh Budaya organisasi $\left(\mathrm{X}_{2}\right)$ terhadap Prestasi kerja guru (Y). Dengan koefisien jalurnya $\rho_{\mathrm{yx} 2}=0,246$. Hasil perhitungan uji individu menunjukkan harga $\mathrm{t}_{\text {hitung }}$ sebesar 2,495 Dengan demikian $t_{\text {hitung }}>t_{\text {tabel }}(1,495>1,981)$. Sehingga Ho ditolak dan H1 diterima, yang artinya koefisien jalur variabel Budaya organisasi $\left(\mathrm{X}_{2}\right)$ berpengaruh terhadap Prestasi kerja guru (Y.

Hipotesis 3

Ho: $\rho_{\mathrm{yz} 3} \leq 0$ : Lingkungan kerja tidak berpengaruh terhadap Prestasi kerja guru

$\mathrm{H}_{1}: \rho_{\mathrm{yx} 3}>0$ : Lingkungan kerja berpengaruh terhadap Prestasi kerja guru

Hipotesis ini menyatakan ada pengaruh Lingkungan kerja berpengaruh terhadap Prestasi kerja guru (Y). Dengan koefisien jalurnya $\rho_{\mathrm{zyx} 3}=0,370$. Hasil perhitungan uji individu menunjukkan harga $\mathrm{t}_{\text {hitung }}$ sebesar 3,742. Dengan demikian $t_{\text {hitung }}>t_{\text {tabel }}(3,742>1,981)$. Sehingga Ha diterima artinya koefisien jalur variabel lingkungan kerja $\left(\mathrm{X}_{3}\right)$ berpengaruh terhadap Prestasi kerja guru $(\mathrm{Y})$, secara signifikan pada taraf uji $\alpha=0,05$.

\section{2). Menentukan Model Struktural}

Setelah terbukti adanya hubungan dan pengaruh secara signifikans anatara variabel eksogen terhadap variabel endogen dalam penelitian ini, lalu dilakukan taksiran nilai kausalitas antar variabel eksogen $\left(\mathrm{X}_{1}\right.$, $\mathrm{X}_{2}, \mathrm{X}_{3}$ ) pada tabel 5, dan taksiran koefisien jalur pada tabel 5, yakni :

Tabel 5. Hubungan Kausal Antar Variabel Bebas (Eksogenus)

\begin{tabular}{|l|l|c|c|c|}
\hline \multirow{3}{*}{$\begin{array}{l}\text { Kepemimpinan Kepala } \\
\text { Sekolah }\end{array}$} & $\begin{array}{c}\text { Kepemimpinan Kepala } \\
\text { Sekolah }\end{array}$ & Budaya Organisasi & Lingkungan Kerja \\
\cline { 2 - 5 } & Pearson Correlation & 1 & $.263^{* *}$ & $.441^{* *}$ \\
\cline { 2 - 5 } & Sig. (2-tailed) & & .004 & .000 \\
\cline { 2 - 5 } & $\mathrm{N}$ & 115 & 115 & 115 \\
\hline \multirow{5}{*}{ Budaya Organisasi } & Pearson Correlation & $.263^{* * *}$ & 1 & .334 \\
\cline { 2 - 5 } & Sig. (2-tailed) & .004 & 115 & .000 \\
\cline { 2 - 5 } & $\mathrm{N}$ & 115 & .334 & 115 \\
\hline \multirow{3}{*}{ Lingkungan Kerja } & Pearson Correlation & $.441^{* * *}$ & .000 & 115 \\
\cline { 2 - 5 } & Sig. (2-tailed) & .000 & 115 & \\
\cline { 2 - 5 } & $\mathrm{N}$ & 115 & & \\
\hline
\end{tabular}

**. Correlation is significant at the 0.01 level (2-tailed).

Berdasarkan antar variabel eksogen, dan nilai koefisien jalur $(\rho)$, maka model kausal yang dibentuk secara teoritik diperoleh diagram jalur seperti gambar 2. 


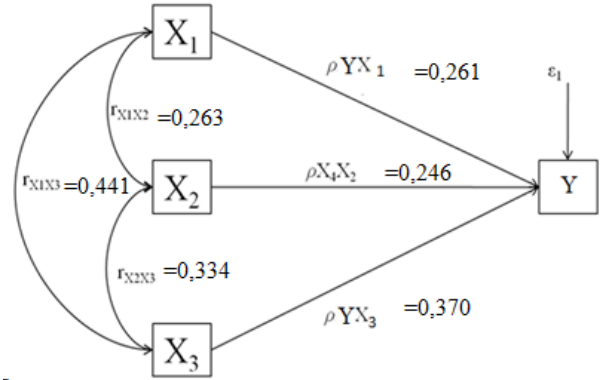

Gambar 2. Diagram Jalur Penelitian

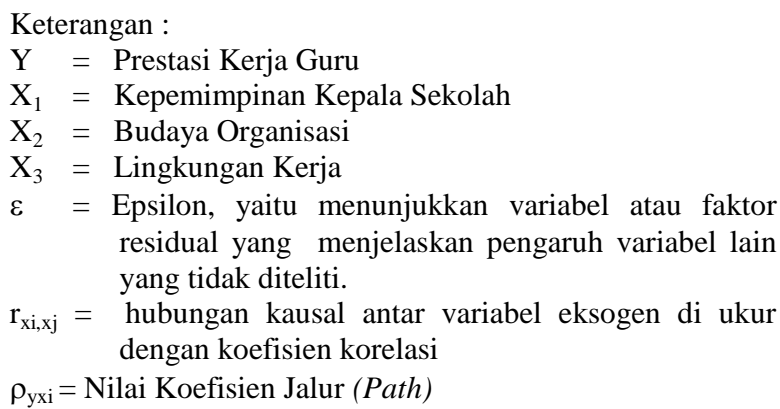

Keterangan :

$\mathrm{X}_{1}=$ Kepemimpinan Kepala Sekolah

$\mathrm{X}_{2}=$ Budaya Organisasi

$\mathrm{X}_{3}=$ Lingkungan Kerja residual yang menjelaskan pengaruh variabel lain ng tidak diteliti.

Koefisien Jalur (Path)

\section{d. Pembahasan}

\section{1). Pengaruh Kepemimpinan Kepala Sekolah terhadap Prestasi kerja Guru}

Hasil analisis data sebelumnya, menunjukkan adanya pengaruh Kepemimpinan Kepala sekolah terhadap Prestasi kerja guru. Adapun besarnya pengaruh, langsung ataupun tidak langsung karena terdapat hubungan kausalitas antara variabel Kepemimpinan Kepala sekolah dengan Budaya Organissi dan lingkungan kerja, ditentukan berikut ini:

Besarnya pengaruh langsung Kepemimpinan Kepala sekolah $\left(\mathrm{X}_{1}\right)$ terhadap Prestasi kerja guru (Y), dinyatakan dengan besaran koefisien jalur $\left(\rho_{\mathrm{zx} 1}=0,261\right)$, Sehingga besarnya pengaruh langsung ini adalah: 6,81 persen.

Besarnya pengaruh tak langsung Kepemimpinan Kepala sekolah $\left(\mathrm{X}_{1}\right)$ terhadap Prestasi kerja guru (Y), karena adanya hubungan kausal dalam variabel eksogen, sehingga di hitung sebagai berikut:

- Pengaruh Kepemimpinan Kepala sekolah dan Budaya organisasi terhadap Prestasi kerja guru, adalah: $(0,261)(0,263)(0,246) \times 100 \%=1,68$

- Pengaruh Kepemimpinan Kepala sekolah dan lingkungan kerja terhadap Prestasi kerja guru, adalah: $(0,261)(0,441)(0,370) \times 100 \%=4,25 \%$

Maka Pengaruh Total Kepemimpnan Kepala Sekolah $\left(\mathrm{X}_{1}\right)$ terhadap Prestasi kerja guru adalah 12,74 persen.

\section{2). Pengaruh Budaya Organisasi terhadap Prestasi kerja Guru}

Hasil analisis data sebelumnya, menunjukkan adanya pengaruh Budaya Organisasi terhadap Prestasi kerja. Adapun besarnya pengaruh langsung ataupun tidak langsung karena terdapat hubungan kausalitas antara variabel Budaya organisasi, dengan Kepemimpinan Kepala Sekolah dan lingkunga kerja, ditentukan berikut ini:

Besarnya pengaruh langsung Budaya organisasi $\left(\mathrm{X}_{2}\right)$ terhadap Prestasi kerja guru $(\mathrm{Y})$, dinyatakan dengan besaran koefisien jalur $\left(\rho_{\mathrm{yx} 2}=0,246\right)$, Sehingga besarnya pengaruh langsung ini adalah: $6,05 \%$.

- Pengaruh Budaya organisasi dan Kepemimpinan Kepala Sekolah terhadap Preatasi kerja guru (Y), adalah: $(0,246)(0,263)(0,261) \times 100 \%=1,68 \%$

- Pengaruh Budaya organisasi dengan lingkungan kerja terhadap Prestasi kerja guru, adalah: $(0,261)$ $(0,334)(0,370) \times 100 \%=3,22 \%$.

Maka Pengaruh Total Budaya organisasi $\left(\mathrm{X}_{2}\right)$ terhadap Prestasi kerja guru SD (Y) adalah 10,95 persen.

\section{3). Pengaruh Lingkungan kerja terhadap Prestasi kerja Guru}

Hasil analisis data sebelumnya, menunjukkan adanya pengaruh Lingkungan kerja terhadap Prestasi kerja Guru. Maka besarnya pengaruh langsung ataupun adanya hubungan kausal dengan Kepemimpinan Kepala Sekolah dan Budaya organisasi, ditentukan berikut ini:

Besarnya pengaruh langsung Lingkungan kerja $\left(\mathrm{X}_{3}\right)$ terhadap Prestasi kerja guru $(\mathrm{Y})$, dinyatakan dengan besaran koefisien jalur $\left(\rho_{\mathrm{yx} 3}=370\right)$, Sehingga besarnya pengaruh langsung ini adalah: 13,69\%.

- Pengaruh Lingkungan kerja dan Kepemimpina Kepala sekolah terhadap Prestasi kerja guru, adalah: $(0,370)(0,441)(0,261) \times 100 \%=\mathbf{4 , 2 5 \%}$.

- Pengaruh Lingkungan kerja dan Budaya oraganisasi terhadap Prestasi kerja guru, adalah: $(0,370)(0,441)$ $(0,246) \times 100 \%=\mathbf{4 , 0 1 \%}$.

Maka pengaruh Total Lingkungan kerja $\left(\mathrm{X}_{3}\right)$ terhadap Prestasi kerja guru $(\mathrm{Y})$, adalah dengan 21,95 persen. 


\section{4). Pengaruh Kepemimpinan Kepala Sekolah, Budaya Organisasi, dan Lingkungan kerja terhadap Prestasi kerja Guru SD}

Berdasarkan model struktural yang dikaji dan dibahas sebelumnya, maka dapat di perdalam dengan melibatkan ketiga faktor yang diduga berpengaruh pada prestasi kerja guru, yakni faktor Kepemimpinan Kepala Sekolah, Budaya Organisasi, dan Lingkungan kerja, terhadap Prestasi kerja guru secara simultan, yakni dengan menghitung korelasi dan determinasi antar variabel ini, yakni sebagai berikut:

a). Korelasi antar Kepemimpinan Kepala Sekolah, Budaya Organisasi, dan Lingkungan kerja, terhadap Prestasi kerja guru secara simultan

Berdasarkan hitungan korelasi dan determinasi antar variabel Kepemimpinan Kepala Sekolah, Budaya Organisasi, dan Lingkungan kerja, terhadap Prestasi kerja, sebagaimana ditunjukkan dalam tabel berikut :

Tabel 6. Korelasi dan Determinasi antar variabel

\begin{tabular}{|c|c|c|c|}
\hline $\mathrm{R}$ & R Square & Adjusted R Square & Std. Error of the Estimate \\
\hline $.714^{\mathrm{a}}$ & .509 & .433 & 2.51554 \\
\hline
\end{tabular}

Maka dari informasi diatas, terdapat sebesar 0,714 korelasi antar variabel Kepemimpinan Kepala Sekolah, Budaya Organisasi, dan Lingkungan kerja, terhadap Prestasi kerja guru. Ini menunjukkan hubungan yang kuat dengar derajat 0,714 dan hubungannya positip.

Dan Hasil koefsiein determinasinya $\left(\mathrm{R}^{2}\right)$ adalah sebesar 0,509 yang dimaknai bahwa terdapat sebesar 50,9 $\%$ kontribusi atau peranan adanya faktor Kepemimpinan Kepala Sekolah, Budaya Organisasi, dan Lingkungan kerja, terhadap peningkatan Prestasi kerja guru. Dan sisanya yakni sekitar 49,1\% dipengaruhi oleh faktor lain, seperti kompensasi, fasilitas, Motivasi dan pelatihan guru, atau lainnya yang mengikat terhadap prestasi kerja guru.

\section{Simpulan (Conclusion)}

Sebagaimana tuan dari penelitian ini, maka dari hasil penelitian dan pembahasan yang dilakukan, dapat ditarik beberapa simpulan penting sebagai rangkuman dan temuan hasil penelitian, yakni:

a) Terdapat pengaruh langsung dan tidak langsung kepemimpinan kepala sekolah terhadap prestasi kerja guru yakni sebesar 12,74 persen.

b) Terdapat pengaruh langsung dan tidak langsung budaya organisasi terhadap prestasi kerja guru, yakni sebesar 10,95 persen.

c) Terdapat pengaruh langsung dan tidak langsung lingkungan kerja terhadap prestasi kerja guru, yakni sebesar 21,95 persen.

d) Berdasarkan ukuran koefisien determinasi sebesar 0,509 menjelaskan bahwa kontribusi aspek kepemimpinan kepala sekolah, budaya organisasi dan lingkungan kerja terhadap prestasi kerja guru sebesar 50,9\%. Sementara sisanya (nilai residu) dari peran variabel yang tidak diteliti sebesar 49,1\%, menujukkan bahwa terdapat faktor-faktor lain yang dapat mempengaruhi variabel prestasi kerja.

\section{DAFTAR PUSTAKA (References)}

1) Abdul Azis Wahab, 2008. Anatomi Organisasi dan Kepemimpinan Pendidikan. Bandung: Alfabeta

2) Alex S. Nitisemito, 2001, Manajemen Personalia, Edisi kedua, Ghalia. Indonesia.

3) Donnelly, James H., James L. Gibson dan John M. Ivancevich, 2003, Fundamentals of Management, Business Publication, Texas

4) E.Mulyasa. 2007. Standar Kompetensi dan Sertifikasi Guru. Bandung: PT. Remaja. Rosdakarya.

5) Marwan Hamid, Ibrahim Sufi, Win Konadi, dan Yusrizal Akmal, 2019. Analisis Jalur Dan Aplikasi

6) Spss Versi 25, Edisi Pertama Sefa Bumi Persada, Medan.

7) Robbins, Stephen. P. 2003. Perilaku Organisasi. Jakarta: Gramedia.

8) Robbins, Stephen P. dan Timothy A. Judge. 2008. Perilaku Organisasi Edisi ke-12,. Jakarta: Salemba Empat.

9) Sedarmayanti. 2001. Sumber Daya Manusia dan Produktivitas Kerja. Bandung: Mandar Maju

10) Sugiyono. 2012. Metode Penelitian Kuantitatif Kualitatif dan R\&B. Bandung: Alfabeta.

11) Sutrisno, Edy. 2010. Manajemen Sumber Daya Manusia. Jakarta: Kencana. Prenada Media Group 
12) Tilaar, H.A.R. 2004. Multikulturalisme: Tantangan-tantangan Global Masa Depan dalam Transformasi Pendidikan Nasional. Jakarta: Grasindo.

13) Trisnantari, Hikmah Eva, 2014. Pemberdayaan Guru Pendidikan Anak Usia Dini (Paud) Di Kecamatan Kedungwaru Dalam Membentuk Karakter Anak Yang Kreatif J-Adimas, Vol 2, No 1 (2014)

14) Nirwana Sitepu, 2014. Analisis jalur, Unpad Bandung

15) Wahyudi.2009. Kepemimpinan Kepala Sekolah Dalam Organisasi Pembelajaran. (Learning Organization). Bandung: Alfabeta.

16) Rivai, Veithzal. 2005. Manajemen Sumber Daya Manusia Untuk Perusahaan, dari Teorike Praktik. PT. Raja Grafindo Persada, Jakarta. 